\title{
Roles of Si and SiNPs in Improving Thermotolerance of Wheat Photosynthetic Machinery via Upregulation of PsbH, PsbB and PsbD Genes Encoding PSII Core Proteins
}

\author{
Heba Hassan ${ }^{1, *}$, Aishah Alatawi ${ }^{2}$, Awatif Abdulmajeed ${ }^{3}$, Manal Emam ${ }^{1}$ and Hemmat Khattab ${ }^{1}$ \\ 1 Botany Department, Faculty of Science, Ain Shams University, Cairo 11566, Egypt; \\ manalemam@sci.asu.edu.eg (M.E.); hemmatkhattab@sci.asu.edu.eg (H.K.) \\ 2 Biology Department, Faculty of Science, University of Tabuk, Tabuk 71421, Saudi Arabia; \\ Amm.alatawi@ut.edu.sa \\ 3 Biology Department, Faculty of Science, University of Tabuk, Umluj 46429, Saudi Arabia; \\ awabdulmajeed@ut.edu.sa \\ * Correspondence: Hebametwally@sci.asu.edu.eg
}

check for updates

Citation: Hassan, H.; Alatawi, A.; Abdulmajeed, A.; Emam, M.; Khattab, H. Roles of $\mathrm{Si}$ and SiNPs in Improving Thermotolerance of Wheat Photosynthetic Machinery via Upregulation of PsbH, PsbB and PsbD Genes Encoding PSII Core Proteins. Horticulturae 2021, 7, 16. https://doi.org/10.3390/

horticulturae7020016

Academic Editor: Sowbiya Muneer

Received: 3 January 2021

Accepted: 21 January 2021

Published: 26 January 2021

Publisher's Note: MDPI stays neutral with regard to jurisdictional claims in published maps and institutional affiliations.

Copyright: (C) 2021 by the authors Licensee MDPI, Basel, Switzerland. This article is an open access article distributed under the terms and conditions of the Creative Commons Attribution (CC BY) license (https:// creativecommons.org/licenses/by/ $4.0 /)$.

\begin{abstract}
Photosystem II is extremely susceptible to environmental alterations, particularly high temperatures. The maintenance of an efficient photosynthetic system under stress conditions is one of the main issues for plants to attain their required energy. Nowadays, searching for stress alleviators is the main goal for maintaining photosynthetic system productivity and, thereby, crop yield under global climate change. Potassium silicate $\left(\mathrm{K}_{2} \mathrm{SiO}_{3}, 1.5 \mathrm{mM}\right)$ and silicon dioxide nanoparticles $\left(\mathrm{SiO}_{2} \mathrm{NPs}_{\text {, }}\right.$ $1.66 \mathrm{mM}$ ) were used to mitigate the negative impacts of heat stress $\left(45^{\circ} \mathrm{C}, 5 \mathrm{~h}\right.$ ) on wheat (Triticum aestivum L.) cv. (Shandawelly) seedlings. The results showed that $\mathrm{K}_{2} \mathrm{SiO}_{3}$ and $\mathrm{SiO}_{2} \mathrm{NPs}_{\text {diminished }}$ leaf rolling symptoms and electrolyte leakage (EL) of heat-stressed wheat leaves. Furthermore, the maximum quantum yield of photosystem II $(\mathrm{Fv} / \mathrm{Fm})$ and the performance index $\left(\mathrm{PI}_{\mathrm{abs}}\right)$, as well as the photosynthetic pigments and organic solutes including soluble sugars, sucrose, and proline accumulation, were increased in $\mathrm{K}_{2} \mathrm{SiO}_{3}$ and $\mathrm{SiO}_{2} \mathrm{NPs}$ stressed leaves. At the molecular level, RT-PCR analysis showed that $\mathrm{K}_{2} \mathrm{SiO}_{3}$ and $\mathrm{SiO}_{2} \mathrm{NPs}$ treatments stimulated the overexpression of $P s b H, P s b B$, and $P s b D$ genes. Notably, this investigation indicated that $\mathrm{K}_{2} \mathrm{SiO}_{3}$ was more effective in improving wheat thermotolerance compared to $\mathrm{SiO}_{2} \mathrm{NPs}$. The application of $\mathrm{K}_{2} \mathrm{SiO}_{3}$ and $\mathrm{SiO}_{2} \mathrm{NPs}_{\text {may be one }}$ of the proposed approaches to improve crop growth and productivity to tolerate climatic change.
\end{abstract}

Keywords: silicon; silicon nanoparticles; photosynthetic performance; $P s b H ; P s b B$ and $P s b D$ genes; wheat

\section{Introduction}

Photosynthesis is a significant solar energy storage process that sustains life on the Earth. Photosynthesis is significantly sensitive to environmental alterations, particularly temperature [1]. Heat stress influences the functional properties of chloroplasts [2,3], including inhibition of the carbon assimilation system [4], decline in the electron transport chain, which in turn stimulates the production of reactive oxygen species [5,6], as well as the reduction in Rubisco activity [4], consequently reducing the photosynthetic capacity under stress conditions [7]. Both photosystems I and II play vital roles in transformation of light energy to ATP molecules [8]. High temperature directly damages the photosynthetic systems, particularly PSII [9], concomitant with distortion of the membrane integrity $[10,11]$. Additionally, chlorophyll fluorescence $\left(\mathrm{Fv} / \mathrm{Fm} ; \mathrm{PI}_{\mathrm{abs}}\right)$ information is considered an important parameter for estimating the photosynthetic apparatus damage in heat-stressed leaves [12]. It has been described that heat stress induces reduction in the ratio of Fv/Fm [13,14]. Furthermore, the functions of both PSI and PSII could be described by the performance index $\left(\mathrm{PI}_{\mathrm{abs}}\right)$ [15]. It was stated that $\mathrm{PI}_{\mathrm{abs}}$ is more susceptible to climatic changes compared to Fv / Fm [16] and could reflect the efficiency of photosynthetic systems 
and $\mathrm{CO}_{2}$ assimilation $[17,18]$. Notably, $\mathrm{PI}_{\mathrm{abs}}$ represents quantitative knowledge on the present state of the stressed plant performance [19]. It was observed that PSII is generally more sensitive to temperature stress [20] compared to PSI [21]. Indeed, plants deal with environmental stresses by regulating the expression of some stress-responsive genes [22]. Heat stress induces alterations in protein factors that are involved in de novo assembly and/or degradation and turnover of the of PSII reaction center proteins. It was documented that the assembly of PSII is controlled by several phosphoproteins such as $P s b H, P s b B$, and $P s b D$ [23]. Meanwhile, PsbD encodes the reaction center protein D2 of PSII [24], while the $p s b B$ gene encodes the photosystem II (PSII) chlorophyll-binding protein of $47 \mathrm{kDa}$ (CP47). It contributes with chlorophyll-binding protein $43 \mathrm{kDa}(\mathrm{CP} 43)$ in the formation of the inner light-harvesting complex [25]. The PSII subunit $\mathrm{H}$ protein $(\mathrm{Ps} b \mathrm{H})$ is essential for PSII activity and is recognized as an $8 \mathrm{kDa}$ phosphoprotein in higher plant chloroplasts [26]. Furthermore, $\mathrm{Ps} b \mathrm{H}$ might play a role in regulating PSII assembly/ stability and repair of photodamaged PSII $[27,28]$. PsbH is necessary to protect the PSII core and the thylakoid membrane from oxidative damage [29].

Plants can tolerate heat stress by evolving different defense strategies such as compatible solute accumulation (e.g., soluble sugar, proline), which participate in maintaining cell turgor via the osmotic adjustment [30,31]. Indeed, soluble sugars perform an important role in gene regulation mechanisms, rather than osmotic adjustment [32]. Meanwhile, proline plays highly protective roles in the antioxidant defense system [33].

Generally, majority of the world's population depends upon wheat as a staple food [34]. Wheat is a winter crop, has an optimum growth temperature at $23-25^{\circ} \mathrm{C}$ and, consequently, it is sensitive to temperature above $25^{\circ} \mathrm{C}$ [35]. Wheat is grown in about $30 \%$ of the world cereal area, and about $50 \%$ of such area experiences heat stress [36]. It was reported that heat stress above the optimum threshold level $\left(25^{\circ} \mathrm{C}\right)$ over a period is enough to induce irreversible damage to the wheat plant [37]. Hence, it is necessary to search for a potent cheap and ecofriendly alleviator to nullify heat stress hazards. It was reported that silicon (Si) enhances the tolerance of several plants against temperature stress [38,39]. It has been reported that $\mathrm{Si}$ deposited in the epidermal and vascular tissue walls of stems and leaves in most plant species, especially monocots, affects the physiological properties of plants [40,41]. In addition, silicon treatment stimulated the overexpression of aquaporin genes associated with improvement in the water status [41], antioxidant activities [42], photosynthetic performance [43], and the expression of antioxidant genes [44]. It was reported that high salinity almost resulted in the disappearance of PSI and PSII complexes; however, Si treatment protected the protein complexes in tomato plants.

Si nanoparticles (SiNPs) are currently considered a novel Si source that can be used to improve plant tolerance against abiotic stresses. A number of studies have explored the effects of seed priming with SiNPs on heat, salinity, and metal-stressed plants [41,45,46]. However, its role in the alleviation of heat stress has not been studied yet. Ultimately, the present investigation explores the effectiveness of Si and SiNPs in the protection of photosynthetic machinery.

\section{Materials and Methods}

\subsection{Materials and Growth Conditions}

Wheat (Triticum aestivum L.) cv. (Shandawelly) grains were obtained from the Agricultural Research Centre, Giza, Egypt. Potassium silicate $\left(\mathrm{K}_{2} \mathrm{SiO}_{3}\right)$ and nanoparticles of silicon dioxide $\left(\mathrm{SiO}_{2} \mathrm{NPs}\right)$ were obtained from Sigma-Aldrich (Lot 637238, St. Louis, MO, USA). $\mathrm{SiO}_{2} \mathrm{NP}$ characteristics were as follows: $99.5 \%$ purity and $20-30 \mathrm{~nm}$ particle size. The $\mathrm{SiO}_{2} \mathrm{NPs}$ were suspended in water by sonicating the silicon particles via an ultrasonicator at $10 \mathrm{MHz}$ for $\sim 40 \mathrm{~min}$ resulting in a partially homogeneous solution. This research was conducted at Faculty of Science, Ain Shams University, Egypt, using two controlled growth chambers, modelV3-DM, Vision Scientific Company, Daejeon, Korea. The grains were surface sterilized by immersion in $1 \%(w / v)$ sodium hypochlorite solution for $5 \mathrm{~min}$, then 
washed three times with sterile distilled water prior to experimental procedures to prevent fungal contamination.

\subsection{Imposition of Treatments}

The experiment was conducted in a completely randomized design. There were 4 treatments replicated 10 times. The sterilized wheat grains were divided into three sets; the first set was soaked in water (control), the second and third sets were soaked in $\mathrm{SiO}_{2} \mathrm{NPs}$ $(1.66 \mathrm{mM})$ or $\mathrm{K}_{2} \mathrm{SiO}_{3}(1.5 \mathrm{mM})$, respectively, for $8 \mathrm{~h}$ at room temperature $\left(25 \pm 2{ }^{\circ} \mathrm{C}\right)$. The soaked grains were then sown in plastic pots $(25 \times 25 \mathrm{~cm})$ containing $2 \mathrm{~kg}$ of mixed soil (clay and sand, 1:1 w/w). The control growth chamber was maintained at optimum temperature, $24 / 18{ }^{\circ} \mathrm{C}$ day/night temperature, $70 \%$ relative humidity, photosynthetic photon flux density (PPFD) of $250 \mu \mathrm{mol} \mathrm{m}^{-2} \mathrm{~s}^{-1}, 16 / 8 \mathrm{~h} \mathrm{light/dark}$ photoperiod. The water holding capacity of the soil was maintained at $80 \%$ throughout the experiments. Water holding capacity (WHC) of the soil was determined using the modified method adopted by [47]. The proper WHC was kept constant throughout the experiment. All plants were grown in the control chamber for $17 \mathrm{~d}$. The untreated plants were divided into two groups. The first group was kept in the optimal temperature chamber, and the other group as well as the $\mathrm{K}_{2} \mathrm{SiO}_{3}$ and $\mathrm{SiO}_{2} \mathrm{NPs}$ treated plants were moved to the other chamber adjusted at $45^{\circ} \mathrm{C}$ for about $5 \mathrm{~h}$. The PPFD and photoperiod settings in the high-temperature treatment were the same as the control chamber. The fully expanded second leaves of all treatments were collected directly after $5 \mathrm{~h}$ exposure to heat, frozen in liquid nitrogen, and then stored at $-80^{\circ} \mathrm{C}$ for biochemical analyses.

\subsection{Methods}

\subsubsection{Leaf Rolling Score}

Leaf rolling score was determined by the visible recognition of leaf rolling in each pot. All pots were given a mean leaf rolling score, ranging from 1 to 5 scales, with 1 being flat and 5 a tightly rolled leaf [48].

\subsubsection{Chlorophyll Fluorescence Measurements}

Chlorophyll a fluorescence measurement was assessed in both control and stressed leaves at the morning hours. The intact flag leaves were adapted to darkness for $30 \mathrm{~min}$ using light-withholding clips. Leaf chlorophyll fluorescence (Fv/Fm) was measured simultaneously using a pulse amplitude modulation portable fluorometer (Handy PEA, Hansatech, Norfolk, UK). After the adaptation of leaves to darkness, a single strong $1 \mathrm{~s}$ light pulse $\left(3500 \mu \mathrm{mol} / \mathrm{m}^{2} / \mathrm{s}\right)$ was applied. Ten replicates were used for each treatment. The fast fluorescence kinetics ( $F_{0}$ to Fm) were recorded during $10 \mu \mathrm{s}$ to $1 \mathrm{~s}$. Plant vitality was characterized by the performance index $\mathrm{PI}_{\mathrm{abs}}$ parameter [19], which was calculated according to the equations described by [49] as follows:

$$
\mathrm{PI}_{\mathrm{abs}}=\frac{1-\left(\mathrm{F}_{0} / \mathrm{F}_{\mathrm{m}}\right)}{\mathrm{M}_{0} / \mathrm{V}_{\mathrm{J}}} \times \frac{\mathrm{F}_{\mathrm{m}}-\mathrm{F}_{0}}{\mathrm{~F}_{0}} \times \frac{1-\mathrm{V}_{\mathrm{J}}}{\mathrm{V}_{\mathrm{J}}} \cdots
$$

where $\mathrm{F}_{0}$ means fluorescence intensity at $50 \mu \mathrm{s}$, Fm represents maximal fluorescence intensity, $\mathrm{V}_{\mathrm{J}}$ is relative variable fluorescence at $2 \mathrm{~ms}$ (J-step), calculated as follows:

$\mathrm{V}_{\mathrm{J}}=\left(\mathrm{F}_{2} \mathrm{~ms}-\mathrm{F}_{0}\right) /\left(\mathrm{Fm}-\mathrm{F}_{0}\right)(4) . \mathrm{M}_{0}$ represents the initial slope of fluorescence kinetics, which can be derived as $\mathrm{M}_{0}=4\left(\mathrm{~F} 300 \mu \mathrm{s}-\mathrm{F}_{0}\right) /\left(\mathrm{Fm}-\mathrm{F}_{0}\right)$. Maximum quantum efficiency of PSII photochemistry $(\mathrm{Fv} / \mathrm{Fm})$ was calculated according to the equation $\mathrm{Fv} / \mathrm{Fm}=\left(\mathrm{Fm}-\mathrm{F}_{0}\right) / \mathrm{Fm}$.

\subsubsection{Estimation of Photosynthetic Pigments}

The photosynthetic pigments in terms of $\mathrm{Chl} \mathrm{a}, \mathrm{Chl} b$, and carotenoids were extracted and measured according to the method of [50]. One gram of fresh leaves was homogenized in $85 \%$ aqueous acetone for $5 \mathrm{~min}$. The homogenate was centrifuged, and the supernatant was made up to $100 \mathrm{~mL}$ with $85 \%$ acetone. The extinction was measured against a blank of 
pure $85 \%$ aqueous acetone at three different wavelengths $(452.5,644$, and $663 \mathrm{~nm})$ by using a spectrophotometer (Spectronic 601, Milton Roy Company, Ivyland, PA, USA).

\subsubsection{Estimation of Carbohydrates}

The soluble carbohydrate contents were determined by reacting $0.1 \mathrm{~mL}$ of the ethanolic extract with $3 \mathrm{~mL}$ of freshly prepared anthrone reagent $(150 \mathrm{mg}$ anthrone $+100 \mathrm{~mL} 72 \%$ $\mathrm{H}_{2} \mathrm{SO}_{4}$ ) in a boiling water bath for $10 \mathrm{~min}$. After cooling, the absorbance was measured at $620 \mathrm{~nm}$ [51]. Moreover, the method used for the determination of sucrose was described by [52], which is based on extraction of sugars with $80 \%$ ethanol followed by destruction of reducing sugars with $30 \% \mathrm{KOH}$ at $40{ }^{\circ} \mathrm{C}$ for $10 \mathrm{~min}$. Further the sucrose content was estimated by the anthrone reagent method.

\subsubsection{Determination of Proline}

The total free proline was assessed by the method described by [53] using ninhydrin reagent. The leaf tissue $(0.5 \mathrm{~g})$ was homogenized with $6 \mathrm{~mL}$ of $3 \%(w / v)$ sulfosalicylic acid solution. An aliquot $(2 \mathrm{~mL}$ ) of the filtrate was taken with $2 \mathrm{~mL}$ ninhydrin reagent and $2 \mathrm{~mL}$ glacial acetic acid, and the mixture was kept in a boiling water bath for one hour. Then, the mixture was cooled in ice and was separated using a separating funnel. The absorbance of the upper phase was read at $520 \mathrm{~nm}$. Proline concentration was determined from a standard curve of proline and calculated as $\mu \mathrm{g} / \mathrm{g}$ fresh weight.

\subsubsection{Determination of Electrolyte Leakage (EL)}

The stress injury was measured by electrolyte leakage as described by [54]. Plant tissue $(0.5 \mathrm{~g})$ was incubated with $20 \mathrm{~mL}$ of de-ionized water for $24 \mathrm{~h}$ at $25^{\circ} \mathrm{C}$. Then, the electrical conductivity of the solution $\left(\mathrm{L}_{1}\right)$ was quantified. Samples were then autoclaved at $120^{\circ} \mathrm{C}$ for $20 \mathrm{~min}$, and then the final conductivity $\left(\mathrm{L}_{2}\right)$ was assessed after equilibration at $25^{\circ} \mathrm{C}$. The EL was determined according to the following equation:

$$
\mathrm{EL} \%=\left(\mathrm{L}_{1} / \mathrm{L}_{2}\right) \times 100
$$

\subsubsection{Estimation of Lipid Peroxidation Products (Conjugated Dienes, CD)}

The lipid peroxidation conjugated dienes were extracted by homogenization of $100 \mathrm{mg}$ of plant tissue in $5 \mathrm{~mL}$ of $96 \%(v / v)$ ethanol. The absorbance of the supernatant was assayed by estimating the increase in absorption at $234 \mathrm{~nm}$ [55]. The CD was calculated from the extinction coefficient of $2.74 \times 104 \mathrm{M}^{-1} \mathrm{~cm}^{-1}$ [56].

\subsubsection{Quantitative Real-Time PCR (qRT-PCR) Analysis}

The total RNA was separated from plant tissue (100 mg) with 30\% PEG6000 using the RNeasy Plant Mini Kit (Qiagen, Amsterdam, The Netherlands). The total RNA (1 $\mu \mathrm{g})$ was transformed into cDNA by reverse transcription using the c.DNA Kit (TaKaRa) following the instructions of the manufacturer. qRT-PCR was conducted on an ABI 7500 system (Applied Biosystems, New York, NY, USA) using TransStart ${ }^{\mathrm{TM}}$ Green qRT-PCR Super Mix Kit (TransGen, Beijing, China). TaActin rRNA (GenBank Accession: AB181991.1) was used as a reference gene to standardize the relative transcriptional abundance and to minimize different copy numbers of cDNA templates [57]. All data were investigated from three replicates based on the $2^{-\Delta \Delta \mathrm{Ct}}$ method [58]. The primers of the $P s b H, P s b B$, and $P s b D$ genes (Table 1) used in the qRT-PCR excluded the highly conserved protein domain and had high efficiency and specificity.

\subsection{Statistical Analysis}

The experimental data presented in this work were statistically analyzed by analysis of variance (ANOVA) using SPSS v20.0 (SPSS Inc., Chicago, IL, USA) software. Statistical significances of the means were compared with the Duncan test at $p \leq 0.05$ levels, and the 
standard error (SE) of the means are shown in tables and figures as mean $\pm \mathrm{SE}$, the number of degrees of freedom $(n)=3$.

Table 1. The primers used for real-time PCR analysis.

\begin{tabular}{|c|c|c|c|}
\hline Primer Name & Primer Sequence $5^{\prime}-3^{\prime}$ & Accession Number & Gene Name \\
\hline PsbHF & TGGCTACACAAACCGTTGAA & \multirow{6}{*}{$\begin{array}{c}\text { NC_002762.1 (70762..70983) } \\
\text { NC_002762.1 (68672..70198) } \\
\text { NC_002762.1 (8995..10056) }\end{array}$} & \multirow{8}{*}{$\begin{array}{l}\text { Photosystem II Reaction } \\
\text { center protein } \mathrm{H}\end{array}$} \\
\hline PsbHR & CCGTCCAGTAAAACGGAAGA & & \\
\hline PsbBF & GGTTTGCCTTGGTATCGTGT & & \\
\hline PsbBR & TCCACATTGGATCCAGAACA & & \\
\hline PsbDF & CGCTTTAGGGGGTGTGTTTA & & \\
\hline PsbDR & GCCCCCATAGTAGCAACAAA & & \\
\hline TaActinF & TGCTATCCTTCGTTTGGACCTT & \multirow[b]{2}{*}{ AB181991.1 } & \\
\hline TaActin $R$ & AGCGGTTGTTGTGAGGGAGT & & \\
\hline
\end{tabular}

\section{Results}

The unstressed wheat leaves remained unrolled during the day, with score $=0$. Meanwhile, imposition of heat stress induced a significant full leaf rolling (about score $=5$ about $100 \%$ ) as compared with those exposed to normal growth temperature (Figures 1 and $2 \mathrm{a}$ ). Leaf rolling symptoms were detected firstly in heat-stressed wheat leaves after about $5 \mathrm{~h}$ from imposition of the temperature $\left(45^{\circ} \mathrm{C}\right)$ regime. On the other hand, $\mathrm{K}_{2} \mathrm{SiO}_{3}$ and $\mathrm{SiO}_{2} \mathrm{NPs}$ treated leaves were almost unrolled, measuring about $\geq 1$ and 2 (5 and 20\%), respectively, Figures 1 and $2 \mathrm{a}$ ) as compared with that of heat-stressed leaves.

Moreover, results showed that the electrolyte leakage level increased in wheat leaves exposed to $45^{\circ} \mathrm{C}$. The greatest increase in electrolyte leakage was measured in stressed

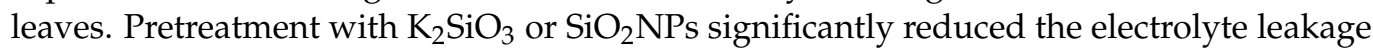
of wheat leaves (Figure 2b). Heat stress increased the EL concomitant with increments in the lipid peroxidation product CD (Figure $2 b, c$ ) compared with those of control unstressed plants.

Likewise, heat-stressed leaves exhibited reductions in $\mathrm{Chl}$ a, Chl b, total chlorophyll content, as well as the carotenoid content (Table 2). However, the ratios of $\mathrm{Chl} \mathrm{a/b}$ of heat-stressed leaves were markedly increased. Interestingly, results showed that $\mathrm{K}_{2} \mathrm{SiO}_{3}$ and $\mathrm{SiO}_{2} \mathrm{NPs}$ treatment enhanced $\mathrm{Chl} \mathrm{a,} \mathrm{Chl} \mathrm{b}, \mathrm{Chl} \mathrm{a}+\mathrm{b}$, total chlorophyll content, and carotenoids concomitant with decline in the $\mathrm{Chl} a / b$ ratio as compared with those of stressed, untreated leaves (Table 2).

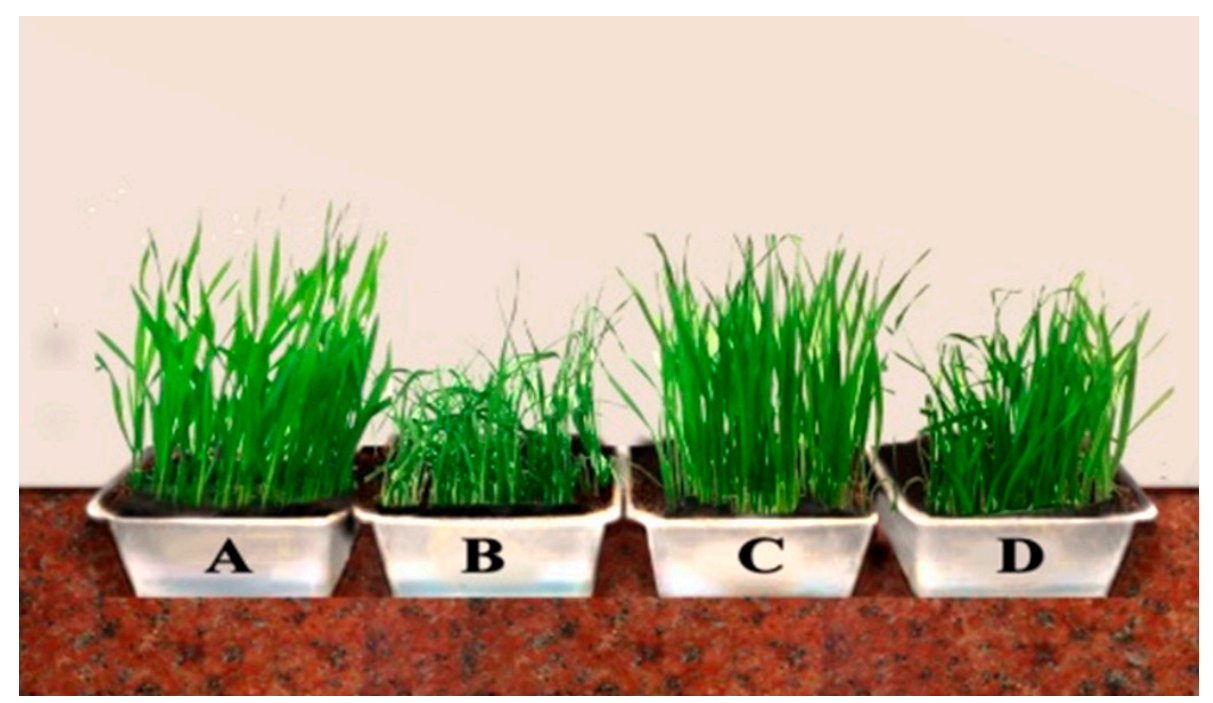

Figure 1. Wheat seedlings exposed to room temperature (A) and $45{ }^{\circ} \mathrm{C}$ for $5 \mathrm{~h}$ in absence (B) and presence of $\mathrm{K}_{2} \mathrm{SiO}_{3}(\mathrm{C})$ or $\mathrm{SiO}_{2} \mathrm{NPs}(\mathrm{D})$. 


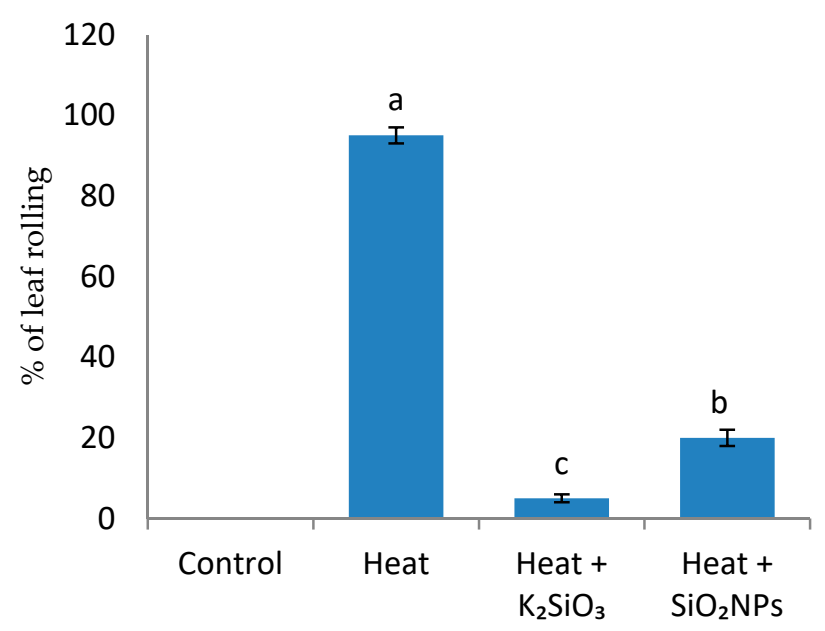

(a)

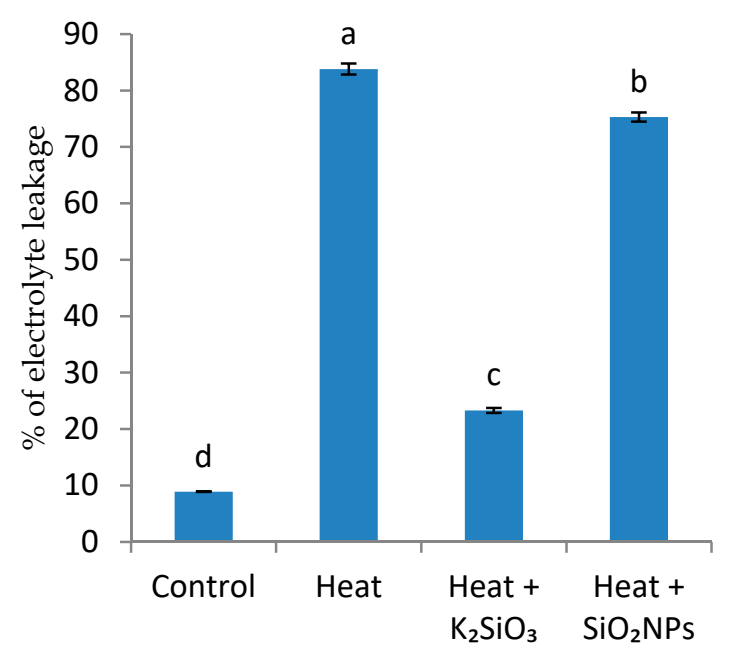

(b)

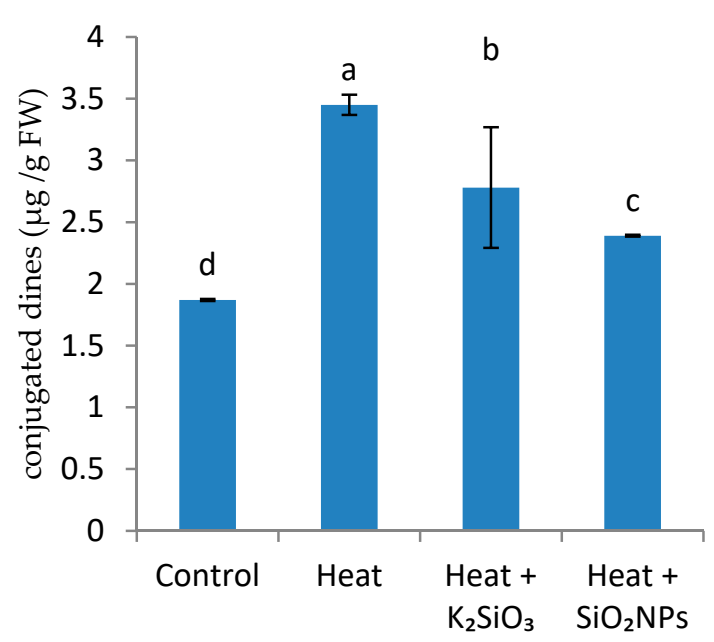

(c)

Figure 2. Effect of $\mathrm{K}_{2} \mathrm{SiO}_{3}$ and $\mathrm{SiO}_{2} \mathrm{NPs}$ treatments on (a) leaf rolling, (b) the percentage of electrolytes leakage (EL), and (c) conjugated dines (CD) $(\mu \mathrm{g} / \mathrm{g}$ FW) of heat-stressed wheat leaves. Each value is the mean of three replicates $\pm \mathrm{SE}$. Columns with different letters are significantly different at $p<0.05$.

Table 2. Effect of $\mathrm{K}_{2} \mathrm{SiO}_{3}$ or $\mathrm{SiO}_{2} \mathrm{NPs}$ on photosynthetic pigments $(\mu \mathrm{g} / \mathrm{g} \mathrm{FW}$ ) of wheat leaves exposed to heat stress. Data are means of three replications $\pm \mathrm{SE}$.

\begin{tabular}{cccccc}
\hline Treatments & Chl (a) & Chl (b) & Chl (a + b) & Carotenoids & $\begin{array}{c}\text { Chlorophyll } \\
\text { a/b Ratio }\end{array}$ \\
\hline Control & $11.3 \pm 0.17 \mathrm{a}$ & $5.5 \pm 0.17 \mathrm{a}$ & $16.8 \pm 0.12 \mathrm{a}$ & $2.5 \pm 0.06 \mathrm{a}$ & $2.05 \pm 0.08 \mathrm{~b}$ \\
$\mathrm{Heat}$ & $6.5 \pm 0.12 \mathrm{c}$ & $2.1 \pm 0.06 \mathrm{c}$ & $8.6 \pm 0.12 \mathrm{~d}$ & $1.6 \pm 0.05 \mathrm{c}$ & $3.0 \pm 0.15 \mathrm{a}$ \\
$\mathrm{Heat}+\mathrm{K}_{2} \mathrm{SiO}_{3}$ & $10.8 \pm 0.17 \mathrm{a}$ & $5.3 \pm 0.13 \mathrm{a}$ & $16.1 \pm 0.12 \mathrm{~b}$ & $2.2 \pm 0.52 \mathrm{~b}$ & $2.3 \pm 0.17 \mathrm{~b}$ \\
Heat $+\mathrm{SiO}_{2} \mathrm{NPs}$ & $9.8 \pm 0.23 \mathrm{~b}$ & $4.3 \pm 0.17 \mathrm{~b}$ & $14.1 \pm 0.04 \mathrm{c}$ & $2 \pm 0.11 \mathrm{~b}$ & $2.03 \pm 0.09 \mathrm{~b}$ \\
\hline Columns with different letters are sionificantly different at $p<0.05$ & & &
\end{tabular}

Columns with different letters are significantly different at $p<0.05$.

Furthermore, thermal stress induced significant reduction in $\mathrm{Fv} / \mathrm{Fm}$ values of stressed wheat leaves (Figure 3a) concomitant with a significant decrease in $\mathrm{PI}_{\mathrm{abs}}$ (Figure 3b). Notably, $\mathrm{K}_{2} \mathrm{SiO}_{3}$ and $\mathrm{SiO}_{2} \mathrm{NPs}$ pretreatment enhanced $\mathrm{Fv} / \mathrm{Fm}$ values and the $\mathrm{PI}_{\mathrm{abs}}$ values 
of heat-stressed leaves compared with that of the untreated stressed ones. The greatest increments in $\mathrm{Fv} / \mathrm{Fm}$ and $\mathrm{PI}_{\mathrm{abs}}$ were attained in $\mathrm{K}_{2} \mathrm{SiO}_{3}$-stressed leaves compared with $\mathrm{SiO}_{2} \mathrm{NPs}$ ones.

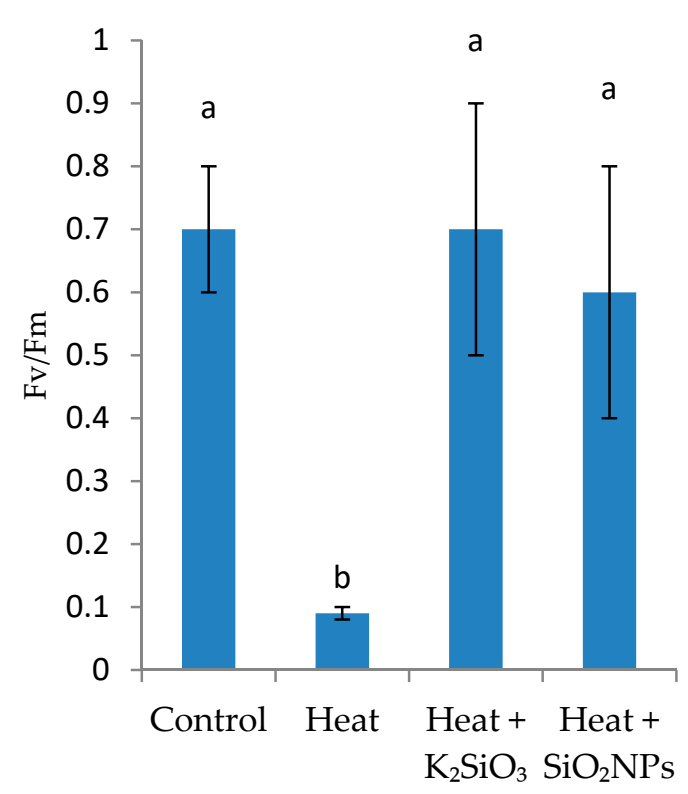

(a)

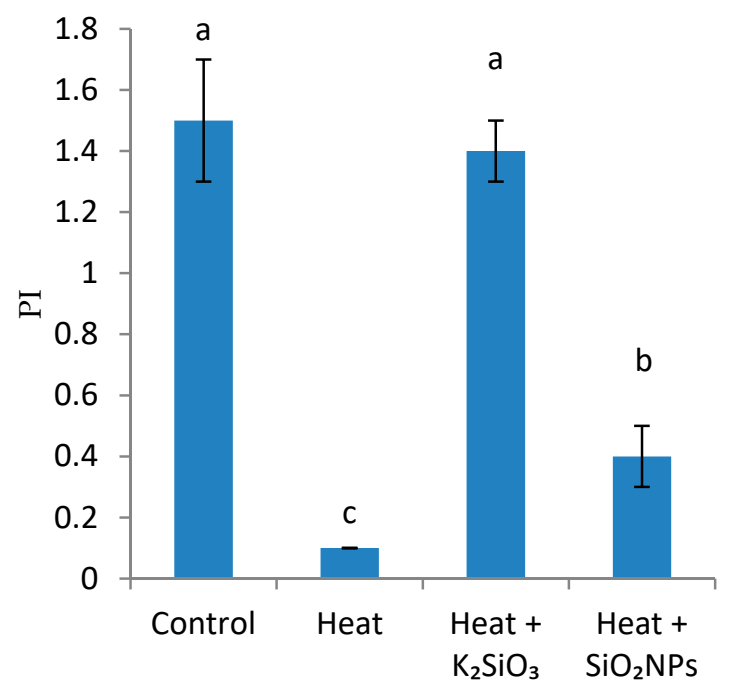

(b)

Figure 3. Effect of $\mathrm{K}_{2} \mathrm{SiO}_{3}$ and $\mathrm{SiO}_{2} \mathrm{NPs}$ treatments on (a) the maximal photochemical efficiency of primary photochemistry $(\mathrm{Fv} / \mathrm{Fm}),(\mathbf{b})$ on the performance index of heat-stressed wheat leaves. Each value is the mean of three replicates $\pm \mathrm{SE}$. Columns with different letters are significantly different at $p<0.05$.

The current data also revealed that imposition of heat stress significantly increased the accumulation of total soluble sugar and sucrose content (Table 3). The accumulation of total soluble sugars as well as sucrose content in heat-treated wheat seedlings increased significantly by $96.7 \%$ and $33.6 \%$, respectively, as compared with their respective controls. Meanwhile, $\mathrm{K}_{2} \mathrm{SiO}_{3}$ and $\mathrm{SiO}_{2} \mathrm{NPs}$ treated seedlings exhibited further increases in the total soluble sugars and sucrose accumulation.

Table 3. Effect of $\mathrm{K}_{2} \mathrm{SiO}_{3}$ or $\mathrm{SiO}_{2} \mathrm{NPs}$ on total soluble sugars ( $\mu$ g glucose equivalent $\mathrm{g}^{-1 \text { F.wt }}$ ), sucrose ( $\mu$ g glucose equivalent $g^{-1 \text { F.wt }}$ ), and proline ( $\mu \mathrm{g}$ proline $\mathrm{g}^{-100 \mathrm{F.wt}}$ ) of wheat leaves exposed to heat stress. Data are means of three replications \pm SE.

\begin{tabular}{|c|c|c|c|}
\hline Treatments & Total Soluble Sugars & Sucrose & Proline \\
\hline Control & $113.6 \pm 0.036 \mathrm{~d}$ & $2.29 \pm 0.030 \mathrm{~d}$ & $26.8 \pm 0.69 \mathrm{~d}$ \\
\hline Heat & $223.5 \pm 0.034 c$ & $3.06 \pm 0.040 \mathrm{c}$ & $46 \pm 0.28 c$ \\
\hline Heat $+\mathrm{K}_{2} \mathrm{SiO}_{3}$ & $330.0 \pm 0.06 \mathrm{a}$ & $5.54 \pm 0.037 \mathrm{a}$ & $86 \pm 0.90 \mathrm{a}$ \\
\hline Heat $+\mathrm{SiO}_{2} \mathrm{NPs}$ & $328.6 \pm 0.04 b$ & $5.28 \pm 0.028 b$ & $57 \pm 0.40 \mathrm{~b}$ \\
\hline
\end{tabular}

Moreover, in this study, heat stress obviously induced a marked increase in proline accumulation compared to the control (Table 3). It was clearly shown that the accumulation of proline level increased significantly in wheat seedlings exposed to heat stress (Table 3). The pretreatment of wheat with $\mathrm{K}_{2} \mathrm{SiO}_{3}$ and $\mathrm{SiO}_{2} \mathrm{NPs}$ enhanced the accumulation of proline in stressed wheat seedlings as compared to those of the controls.

In addition, RT-PCR analysis showed that heat stress downregulated $P s b H, P s b B$, and $P s b D$ expressions (Figure $4 \mathrm{a}-\mathrm{c}$ ). Meanwhile, $\mathrm{K}_{2} \mathrm{SiO}_{3}$ and $\mathrm{SiO}_{2} \mathrm{NPs}$ treatments stimulated the overexpression of $P s b H, P s b B$, and $P s b D$ of heat-stressed wheat leaves compared to 
those of unstressed leaves (Figure $4 \mathrm{a}-\mathrm{c}$ ). Notably, $\mathrm{K}_{2} \mathrm{SiO}_{3}$ treatment attained the greatest $P s b H, P s b B$, and $P s b D$ gene overexpression in wheat leaves exposed to heat stress.

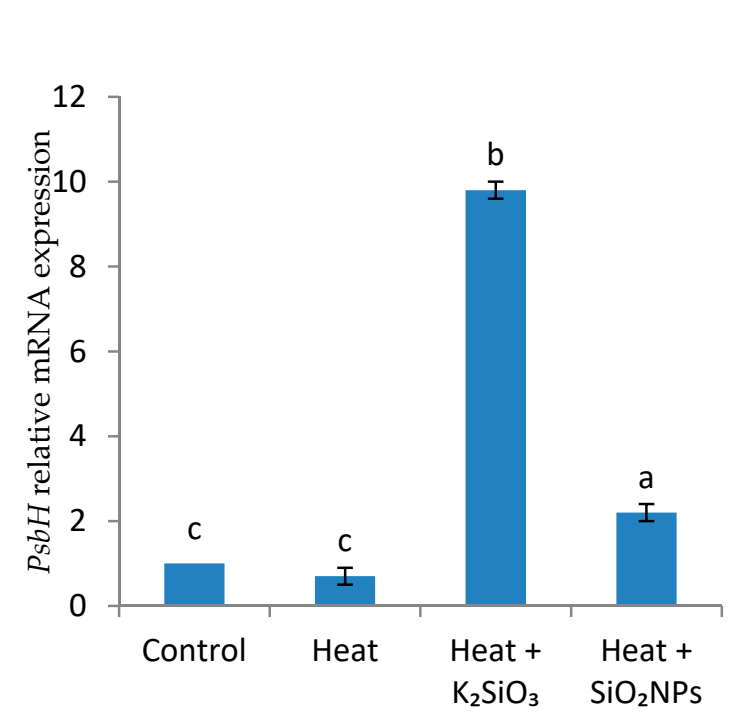

(a)

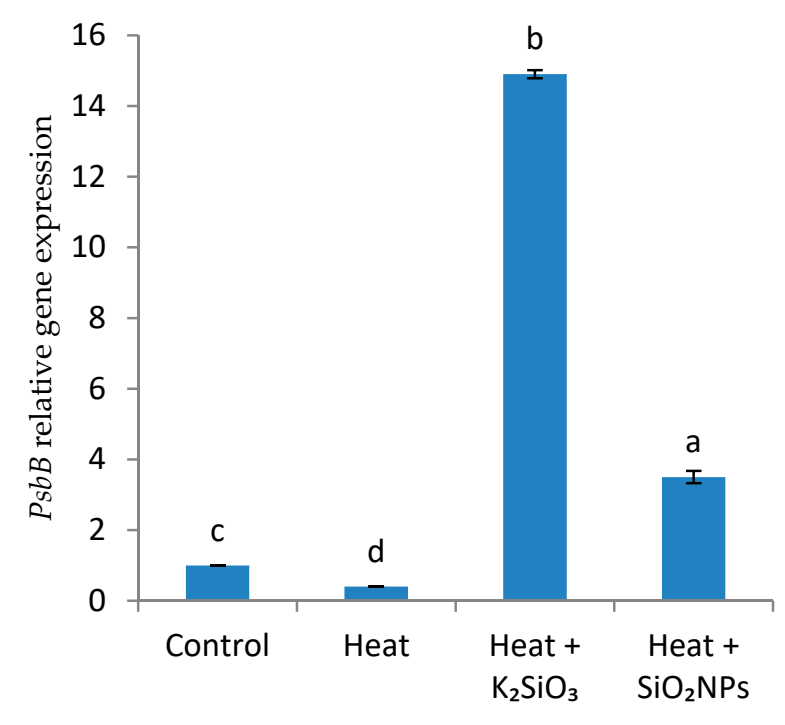

(b)

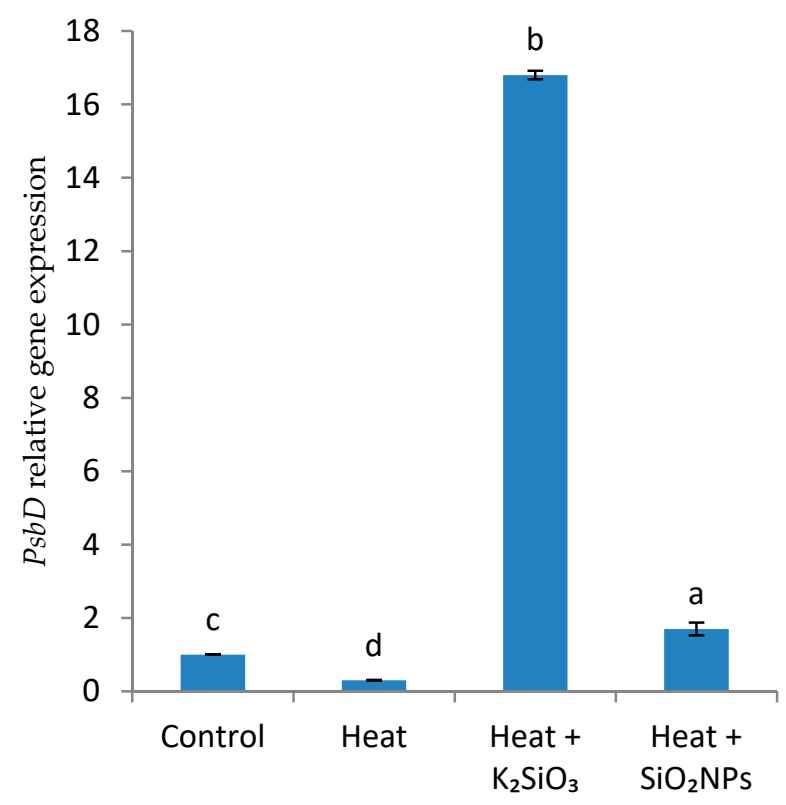

(c)

Figure 4. Effect of $\mathrm{K}_{2} \mathrm{SiO}_{3}$ and $\mathrm{SiO}_{2} \mathrm{NPs}$ treatments on mRNA expression of photosystem II reaction center proteins (a) $\mathrm{H}$ $(P s b H),(\mathbf{b})(P s b B)$, and $(\mathbf{c})(P s b D)$ of heat-stressed wheat leaves. Each value is the mean of three replicates \pm SE. Columns with different letters are significantly different at $p<0.05$.

\section{Discussion}

Heat is an important environmental determinant that could affect the morphological and physiological parameters of plants. Thus, imposition of heat stress induced a significant full leaf rolling of wheat seedlings as compared with those exposed to normal growth temperature (Figure 2a). Leaf rolling symptoms were detected firstly in heat-stressed wheat leaves after about $5 \mathrm{~h}$ from imposition of the temperature $\left(45^{\circ} \mathrm{C}\right)$ regime (Figure 1). Leaf rolling is a heat avoidance strategy that reduces the interception of solar radiation 
and thereby decreases leaf temperature and water loss via transpiration [59]. However, $\mathrm{K}_{2} \mathrm{SiO}_{3}$ and $\mathrm{SiO}_{2} \mathrm{NPs}$ treated leaves displayed lower rolling symptoms compared with heat-stressed leaves (Figure 2a). The impedance of leaf rolling by Si pretreatments may be attributed to the development of a double layer of cuticle silica, which consequently reduces the transpiration rate, decreasing the opening of stoma and limiting the loss of water $[60,61]$. Moreover, deposition of $\mathrm{Si}$ in the plant cell wall enhanced its rigidity and consequently increased leaf erectness $[62,63]$. In addition, the ameliorative effect of $\mathrm{SiO}_{2} \mathrm{NPs}$ might be due to the increments in the irregular deposition of $\mathrm{SiO}_{2} \mathrm{NPs}$ in the epicuticular layer of stressed leaves [64] as well as in the cell walls, the intercellular space, cytoplasm, and in cell organelles. Thus, deposition of SiNPs reduced the cuticular transpiration and maintained plant water use efficiency [65].

Likewise, cell membrane distortion is one of the major damages caused by heat stress, thereby stimulating cell permeability and electrolyte leakage [66]. Heat stress increased the EL concomitant with increments in the lipid peroxidation product CD (Figure $2 b, c)$ as compared with those of control unstressed leaves. Meanwhile, pretreatment with $\mathrm{K}_{2} \mathrm{SiO}_{3}$ or $\mathrm{SiO}_{2} \mathrm{NPs}$ significantly reduced the EL and $\mathrm{CD}$ (Figure $2 \mathrm{~b}, \mathrm{c}$ ) as compared with stressed wheat seedlings. This finding matches those investigated by [67] on stressed rice. Si treatment enhanced the thermal stability of cell membranes via preventing the distortion of cell membranes and ion leakage and, therefore, increased plant resistant against stresses $[61,68,69]$. The alterations in the membrane systems induced by environmental stresses were concomitant with leaf rolling, inadequate light interception, and consequent reduction in photosynthetic activities [70]. Indeed, estimation of chlorophyll content is usually taken as an indicator that reflects a plant's resistance to stress. Estimation of the photosynthetic pigment contents showed that heat stress significantly reduced $\mathrm{Chl} a, \mathrm{Chl} b$, and the total chlorophyll content (Table 2). Such effect might be attributed to the injury of thylakoid membranes, which may lead to chlorophyll loss [71,72]. Likewise, the impact of heat stress on the pigments and other photosynthetic performances has been reported by [73] on sorghum, [74] on maize, and [75] on wheat plants. Meanwhile, the decrease in $\mathrm{Chl} \mathrm{a}+\mathrm{b}$ content by heat may be attributed to the reduction in biosynthesis and/or to the degradation of the pigments [76]. The reduction in carotenoids in wheat leaves could have serious consequences for the effect of heat on chlorophyll pigments [77]. The observed increments in $\mathrm{Chl} \mathrm{a} / \mathrm{b}$ in heat-stressed seedlings may be related to the degradation of chlorophyll $\mathrm{b}$ by high temperature, which in turn may reduce the light-harvesting chlorophyll a/b-binding proteins (LHC) [78]. Interestingly, the present study showed that $\mathrm{K}_{2} \mathrm{SiO}_{3}$ and $\mathrm{SiO} 2 \mathrm{NPs}$ treatment could notably enhance $\mathrm{Chl}$ a, $\mathrm{Chl} \mathrm{b}$, total chlorophyll content, and carotenoids concomitant with decline in the $\mathrm{Chl} \mathrm{a/b}$ ratio, thereby resulting in higher survival rates in stressed wheat seedlings (Figure 1). Si and SiNP treatments can delay chlorophyll degradation and improve photosynthetic capacity in plants under abiotic stresses [42]. The increases in both chl. $\mathrm{a}+\mathrm{b}$ and carotenoid content were concomitant with

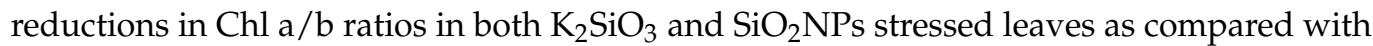
those of stressed untreated leaves (Table 2). Such effect may be attributed to the role of Si in protecting chlorophyll from oxidation by carotenoids [79]. Carotenoids act as an important antioxidant, protecting pigments from the oxidation induced by stressful conditions [80]. Similarly, it was stated that Si-mediated improvement of the chloroplast ultrastructure and chlorophyll contents enhanced the photosynthetic efficiency in stressed plants $[42,81,82]$. Likewise, SiNPs increased the photosynthetic parameters of stressed cherry tomatoes and strawberry plants [62,83]. SiNPs stimulated stabilization of the epicuticular wax structure, chlorophyll content, as well as carotenoid content [64]. Moreover, SiNPs are characterized by their high reactivity and can directly bind with PSII and stabilize the photosynthetic activity [84] under stress conditions.

Moreover, quantitative information on the current state of plant performance under stress conditions could be explored via $\mathrm{PI}_{\mathrm{abs}}$ and $\mathrm{Fv} / \mathrm{Fm}$ measurements [14,19]. The observed reduction in the values of Fv/Fm in stressed wheat leaves (Figure 3a) may result from the conformational changes of the reaction center of PSII [85], which causes imbalance 
between the generation and utilization of electrons [11,12]. Meanwhile, it was observed that $\mathrm{PI}_{\mathrm{abs}}$ decreased in heat-stressed wheat leaves (Figure 3b). High temperatures might induce cleavage and aggregation of reaction center proteins $[86,87]$ and, consequently, the conversion of excitation energy to electron transport [88]. Interestingly, $\mathrm{K}_{2} \mathrm{SiO}_{3}$ and $\mathrm{SiO}_{2} \mathrm{NPs}$ pretreatment enhanced both $\mathrm{Fv} / \mathrm{Fm}$ and the $\mathrm{PI}_{\mathrm{abs}}$ values of heat-stressed leaves compared with that of the untreated stressed ones. The greatest increases in the $\mathrm{Fv} / \mathrm{Fv}$ and the $\mathrm{PI}_{a b s}$ values were achieved in $\mathrm{K}_{2} \mathrm{SiO}_{3}$ treated leaves (Figure 3a,b). Such increases in $\mathrm{Fv} / \mathrm{Fm}$ and $\mathrm{PI}_{\mathrm{abs}}$ values in $\mathrm{K}_{2} \mathrm{SiO}_{3}$ treated leaves may be related with the enhanced density of the PSII active reaction centers [89], which indicates that Si was capable to nullify the harmful effects of heat stress on the photochemical reactions [90,91].

Meanwhile, the tolerant mechanism was associated with osmotic adjustment. This process involves accumulation of some osmolytes such as total soluble sugars, sucrose, and proline, which reduced the cell osmotic potential, reduced water losses, and resulted in the increase in leaf turgor [92]. The current data revealed that imposition of heat stress significantly increased the total soluble sugar and sucrose contents (Table 3), which may be ascribed to the impairing of sucrose-metabolizing enzymes [93]. Soluble sugars and sucrose serve as osmo-protectants, carbon sources, and free radical scavengers [94], and so it may be an Si strategy in improving wheat tolerance against heat stress. Furthermore, proline accumulation is another strategy that has been implicated in the tolerance mechanism of several stressed plant species. In the present investigation, heat stress obviously induced a marked accumulation of proline compared to the control (Table 3). Such obtained results are concomitant with those reported by [95] on rice and [96] on sugar cane. The accumulation of proline under heat stress could also serve as chaperones, stabilizing and protecting the structure of enzymes and proteins, maintaining membrane integrity and scavenging ROS, and as nitrogen and carbon pools $[96,97]$. Pretreatment of wheat with $\mathrm{K}_{2} \mathrm{SiO}_{3}$ and $\mathrm{SiO}_{2} \mathrm{NPs}$ alleviated the adverse effects of heat stress via increasing photosynthetic pigments and organic solutes, including soluble sugars, sucrose, and proline content (Table 3). Similarly, the application of silicon significantly increased sucrose and fructose levels in salt-stressed sorghum [98]. The improving effect of Si treatment on carbohydrates may be attributed to enhancement of the plant performance via adjusting the leaf position and as well its light interception [99]. The greatest increase in proline accumulation in Si-treated plants may be evidence for the alleviation of stress damage. Similarly, proline was accumulated in stressed maize plants [100]. Such an increment in proline level may be due to increased proline synthesis or reduction in proline degradation [101]. It was reported that the improvement in rice tolerance to salt stress by $\mathrm{Si}$ and SiNPs treatments was concomitant with increases in photosynthetic rate, antioxidants, proline, and water use efficiency traits [102].

In addition, photosystem II is extremely sensitive to high-temperature stress. It has been reported that high temperatures disrupt the water-oxidizing complex (WOC), lightharvesting complex, and PSII reaction center [103]. It has been suggested that there is a link between chloroplast gene expression and environmental stress responses [22]. In the current study, RT-PCR analysis showed that heat stress repressed the expressions of $P s b H, P s b B$, and $P s b D$ genes, which were associated with inactivation of PSII as revealed by the reduction in $\mathrm{Fv} / \mathrm{Fm}$ and the photosynthetic performance index $\left(\mathrm{PI}_{\mathrm{abs}}\right)$. Such negative effects of heat stress were concomitant with reductions in the photosynthetic pigment levels and organic solutes, including soluble sugars, sucrose, and proline (Tables 2 and 3 ). The chloroplast gene PsbD encodes the reaction center protein D2 of PSII [104]. Meanwhile, the $p s b B$ gene encodes the photosystem II (PSII) chlorophyll-binding protein (CP47) [25]. The PSII subunit $\mathrm{H}$ protein $(\mathrm{PsbH})$ is also an important phosphoprotein for PSII activity in the chloroplasts. The phosphorylation of PSII proteins regulated the stability, degradation, and turnover of the reaction center proteins [105]. However, dephosphorylation of these proteins was stimulated under stressful conditions $[106,107]$. It was reported that salt stress caused the destruction of D1 protein (encoded by the PsbA gene) in Avena sativa plants concomitant with downregulation of $P s b A, P s b B, P s b C$, and $P s b D$ [108]. Phosphorylation and dephosphorylation of PSII are the main regulatory aspects, and they play a major role 
in PSII repair [109]. However, no attention has been paid to explore the roles of Si and SiNPs on chloroplast phosphorylation and dephosphorylation of PSII at the molecular level, particularly in response to high-temperature stress. The effects of $\mathrm{K}_{2} \mathrm{SiO}_{3}$ and $\mathrm{SiO}_{2} \mathrm{NPs}$ on the core PSII proteins were estimated via RT-PCR analysis of PsbB (CP47 subunit of PSII), $P s b D$ (D2 subunit of PSII), and $P s b H$ (8 kDa phosphoprotein) expressions. RT-PCR results indicated that $P s b B, P s b D$, and $P s b H$ genes encoding extrinsic and intrinsic PSII proteins were upregulated in $\mathrm{K}_{2} \mathrm{SiO}_{3}$ and $\mathrm{SiO}_{2} \mathrm{NPs}$ treated stressed leaves (Figure $4 \mathrm{a}-\mathrm{c}$ ). Notably, the expression of the investigated genes was highly remarkable in $\mathrm{K}_{2} \mathrm{SiO}_{3}$ treated leaves compared with $\mathrm{SiO}_{2} \mathrm{NPs}$ leaves. Si greatly ameliorated the hazards induced by heat stress. Similarly, various stresses are known to cause damage to the D2 protein (encoded by the $P s b D$ gene) $[110,111]$, which is associated with the substantial lower abundance of $P s b D$ transcripts in heat-treated plants. $P s b H$ plays a vital role in activating the heat stress transcription network [112]. In addition, the upregulation of $P s b H$ expression in the Si or SiNPs treated leaves could participate in the stability and repair of PSII after exposure to heat stress [113]. It has been observed that $P s b H$ is involved in photoprotection against the damaging effects of reactive oxygen species [112,114]. $\mathrm{K}_{2} \mathrm{SiO}_{3}$ regulates $P s b H, P s b B$, and $P s b D$ expressions under high-temperature stress conditions (Figure $4 \mathrm{a}-\mathrm{c}$ ) and may accelerate the repair of PSII, thus decreasing the damage of the photosynthetic apparatus induced by heat stress (reviewed by [109]) and improving the repair of photosystem II (PSII) by maintaining overexpression of $P_{s b H}, P_{s b B}$, and $P_{s b D}$, establishing a consistent flow of electrons. Consequently, the overexpression of $P s b H, P s b B$, and $P s b D$ by $\mathrm{K}_{2} \mathrm{SiO}_{3}$ treatment might protect the photosynthetic machinery under heat stress conditions, thereby improving the photosynthetic system efficiency and alleviating the harmful effects of heat. Further studies are required to elucidate the roles of $\mathrm{K}_{2} \mathrm{SiO}_{3}$ and $\mathrm{SiO}_{2} \mathrm{NPs}$ in regulation of $P s b H, P s b B$, and $P s b D$ expressions at the transcriptional level.

\section{Conclusions}

The results of the current investigation provide molecular and physiological evidence supporting the vital roles of $\mathrm{K}_{2} \mathrm{SiO}_{3}$ and $\mathrm{SiO}_{2} \mathrm{NPs}$ in sustaining photosynthetic activity in heat-stressed wheat seedlings, which may have a beneficial impact in horticultural crop management to tolerate climatic fluctuations. The obtained results revealed that $\mathrm{K}_{2} \mathrm{SiO}_{3}$ and $\mathrm{SiO}_{2} \mathrm{NPs}$ alleviated the injuries caused by thermal stress through physical protection and biochemical strategies, which contribute to the protection of the photosystems as well as photosynthetic activity. Such a protective effect was evident by the obtained reductions in photosynthetic parameters of chlorophyll fluorescence $\left(\mathrm{PI}_{\mathrm{abc}}, \mathrm{Fv} / \mathrm{Fm}\right), \mathrm{EL}$, and $\mathrm{CD}$ accumulation. Notably, $\mathrm{K}_{2} \mathrm{SiO}_{3}$ was more effective than $\mathrm{SiO}_{2} \mathrm{NPs}$ in improving wheat thermotolerance. Meanwhile, $\mathrm{K}_{2} \mathrm{SiO}_{3}$ highly induced the expression of PSII-related genes $(P s b H, P s b B, P s b D)$, which might be involved in the regulation of a complex network that confers protection of photosystem II from heat-induced oxidative damages and thereby enhances the photosynthetic capacity of wheat leaves. The greater enhancement effects of $\mathrm{K}_{2} \mathrm{SiO}_{3}$ compared to $\mathrm{SiO}_{2} \mathrm{NPs}$ are perhaps due to the synergistic effects of $\mathrm{Si}$ and $\mathrm{K}$ forming $\mathrm{K}_{2} \mathrm{SiO}_{3}$. Further work will be conducted to study the synergistic effects of some minerals with biogenic SiNPs, which can be used as a nanofertilizer. There are no investigations exploring the synergetic effects of SiNPs with K. Therefore, further in-depth biochemical and molecular studies are necessary to understand the key interactions of signaling pathways concerning the role of either Si or SiNPs in alleviation of stress hazards.

Author Contributions: H.K. and M.E. conceived and planned the experiments. H.H. performed the experiments. A.A. (Aishah Alatawi) and A.A. (Awatif Abdulmajeed) contributed to sample preparation and formal analysis. H.K. and M.E. contributed to the interpretation of the results. H.K. took the lead in writing the manuscript. All authors provided critical feedback and helped shape the research, analysis, and manuscript. All authors have read and agreed to the published version of the manuscript.

Funding: This research received no external funding. 
Conflicts of Interest: The authors declare no conflict of interest.

\begin{tabular}{|c|c|}
\hline Chl a & chlorophyll a \\
\hline $\mathrm{Chl} \mathrm{b}$ & chlorophyll b \\
\hline EL & electrolyte leakage \\
\hline $\mathrm{Fv} / \mathrm{Fm}$ & maximum quantum yield of photosystem II \\
\hline $\mathrm{PI}_{\mathrm{abs}}$ & performance index \\
\hline$P s b H, P s b B$, and $P s b D$ & photosystem II reaction center protein $\mathrm{H}, \mathrm{B}$, and D \\
\hline PSII & photosystem II \\
\hline $\mathrm{Si}$ & silicon \\
\hline SiNPs & silicon nanoparticles \\
\hline WHC & water holding capacity \\
\hline
\end{tabular}

\section{References}

1. Tan, W.; Meng, Q.W.; Brestic, M.; Olsovska, K.; Yang, X. Photosynthesis is improved by exogenous calcium in heat-stressed tobacco plants. J. Plant Physiol. 2011, 168, 2063-2071. [CrossRef] [PubMed]

2. Wang, Q.L.; Chen, J.H.; He, N.Y.; Guo, F.Q. Metabolic reprogramming in chloroplasts under heat stress in plants. Int. J. Mol. Sci. 2018, 19, 849. [CrossRef] [PubMed]

3. Paul, P.; Mesihovic, A.; Chaturvedi, P.; Ghatak, A.; Weckwerth, W.; Böhmer, M.; Schleiff, E. Structural and Functional Heat Stress Responses of Chloroplasts of Arabidopsis thaliana. Genes 2020, 11, 650. [CrossRef] [PubMed]

4. Sharkey, T.D. Effects of moderate heat stress on photosynthesis: Importance of thylakoid reactions, rubisco deactivation, reactive oxygen species, and thermotolerance provided by isoprene. Plant Cell Environ. 2005, 28, 269-277. [CrossRef]

5. Taylor, N.L.; Tan, Y.F.; Jacoby, R.P.; Millar, A.H. Abiotic environmental stress induced changes in the Arabidopsis thaliana chloroplast, mitochondria and peroxisome proteomes. J. Proteom. 2009, 72, 367-378. [CrossRef]

6. Allakhverdiev, S.I.; Kreslavski, V.D.; Klimov, V.V.; Los, D.A.; Carpentier, R.; Mohanty, P. Heat stress: An overview of molecular responses in photosynthesis. Photosynth. Res. 2008, 98, 541. [CrossRef]

7. Law, R.D.; Crafts-Brandner, S.J. Inhibition and acclimation of photosynthesis to heat stress is closely correlated with activation of ribulose-1, 5-bisphosphate carboxylase/oxygenase. Plant Physiol. 1999, 120, 173-182. [CrossRef]

8. Nelson, N.; Junge, W. Structure and energy transfer in photosystems of oxygenic photosynthesis Effect of silicon on drought tolerance of upland rice. Annu. Rev. Biochem. 2015, 84, 659-683. [CrossRef]

9. Lu, C.M.; Zhang, J.H. Heat-Induced multiple effects on PSII in wheat plants. J. Plant Physiol. 2000, 156, 259-265. [CrossRef]

10. Dankov, K.; Rashkov, G.; Misra, A.; Apostolova, E.L. Temperature sensitivity of photosystem II in isolated thylakoid membranes from fluridone-treated pea leaves. Turk. J. Bot. 2015, 39, 420-428. [CrossRef]

11. Li, H.; Xu, H.; Zhang, P.; Gao, M.; Wang, D.; Zhao, H. High temperature effects on D1 protein turnover in three wheat varieties with different heat susceptibility. Plant Growth Regul. 2017, 81, 1-9. [CrossRef]

12. Li, L.; Yang, H.; Liu, P.; Ren, W.; Wu, X.; Huang, F. Combined impact of heat stress and phosphate deficiency on growth and photochemical activity of sheep grass (Leymus chinensis). J. Plant Physiol. 2018, 231, 271-276. [CrossRef] [PubMed]

13. Teixeira, E.I.; Fischer, G.; Van Velthuizen, H.; Walter, C.; Ewert, F. Global hot-spots of heat stress on agricultural crops due to climate change. Agric. For. Meteorol. 2013, 170, 206-215. [CrossRef]

14. Porcar-Castell, A.; Tyystjarvi, E.; Atherton, J.; van der Tol, C.; Flexas, J.; Pfundel, E.E.; Moreno, J.; Frankenberg, C.; Berry, J.A. Linking chlorophyll a fluorescence to photosynthesis for remote sensing applications: Mechanisms and challenges. J. Exp. Bot. 2014, 65, 4065-4095. [CrossRef]

15. Strasser, R.; Srivastava, A.; Tsimilli-Michael, M. The fluorescence transient as a tool to characterize and screen photosynthetic samples. In Probing Photosynthesis: Mechanism, Regulation and Adaptation; Yunus, M., Pathre, U., Mohanty, P., Eds.; Taylor and Francis: London, UK, 2000; pp. 445-483.

16. Brestic, M.; Zivcak, M. PSII fluorescence techniques for measurement of drought and high temperature stress signal in crop plants: Protocols and applications. In Molecular Stress Physiology of Plants; Rout, G., Das, A., Eds.; Springer: New Delhi, India, 2013; pp. 87-131.

17. Van Heerden, P.D.; Tsimilli-Michael, M.; Krüger, G.H.; Strasser, R.J. Dark chilling effects on soybean genotypes during vegetative development: Parallel studies of $\mathrm{CO}_{2}$ assimilation, chlorophyll a fluorescence kinetics O-J-I-P and nitrogen fixation. Physiol. Plant. 2003, 117, 476-491. [CrossRef]

18. Ripley, B.S.; Redfern, S.P.; Dames, J.F. Quantification of the photosynthetic performance of phosphorus-deficient Sorghum by means of chlorophyll-a fluorescence kinetics. S. Afr. J. Sci. South 2004, 100, 615-618.

19. Strasser, R.J.; Tsimilli-Michael, M.; Srivastava, A. Analysis of the fluorescence transient. In Chlorophyll fluorescence: A signature of photosynthesis; Advances in Photosynthesis and Respiration Series; George, C., Papageorgiou, C., Govindjee, G., Eds.; Springer: Dordrecht, The Netherlands, 2004; pp. 321-362. 
20. Mohanty, P.; Kreslavski, V.D.; Klimov, V.V.; Los, D.A.; Mimuro, M.; Carpentier, R.; Allakhverdiev, S.I. Heat stress: Susceptibility, recovery and regulation. In Photosynthesis: Plastid Biology, Energy Conservation and Carbon Assimilation; Eaton-Rye, J.J., Tripathy, B.C., Sharkey, T.D., Eds.; Springer: Dordrecht, The Netherlands, 2012; pp. 251-274.

21. Yan, K.; Chen, P.; Shao, H.; Zhao, S. Characterization of photosynthetic electron transport chain in bioenergy crop Jerusalem artichoke (Helianthus tuberosus L.) under heat stress for sustainable cultivation. Ind. Crop. Prod. 2013, 50, 809-815. [CrossRef]

22. Zhang, Y.; Zhang, A.; Li, X.; Lu, C. The Role of Chloroplast Gene Expression in Plant Responses to Environmental Stress. Int. J. Mol. Sci. 2020, 21, 6082. [CrossRef]

23. Vener, A.V. Environmentally modulated phosphorylation and dynamics of proteins photosynthetic membranes. Biochim. Biophys. Acta 2007, 1767, 449-457. [CrossRef]

24. Yao, W.B.; Meng, B.Y.; Tanaka, M.; Sugiura, M. An additional promoter within the protein-coding region of the psb D-psb C gene cluster in tobacco chloroplast DNA. Nucleic Acids Res. 1989, 17, 9583-9591. [CrossRef]

25. Barber, J.; Nield, J.; Morris, E.P.; Zheleva, D.; Hankamer, B. The structure, function and dynamics of photosystem two. Physiol. Plant. 1997, 100, 817-827. [CrossRef]

26. Vener, A.V.; Harms, A.; Sussman, M.R.; Vierstra, R.D. Mass spectrometric resolution of reversible protein phosphorylation in photosynthetic membranes of Arabidopsis thaliana. J. Biol. Chem. 2001, 276, 6959-6966. [CrossRef] [PubMed]

27. Bennett, J. Phosphorylation of chloroplast membrane polypeptides. Nature 1977, 269, 344-346. [CrossRef]

28. Shi, L.X.; Schröder, W.P. The low molecular mass subunits of the photosynthetic supracomplex, photosystem II. Biochim. Biophys. Acta Bioenerg. 2004, 1608, 75-96. [CrossRef]

29. Huang, W.; Yang, Y.J.; Hu, H.; Zhang, S.B.; Cao, K.F. Evidence for the role of cyclic electron flow in photoprotection for oxygen-evolving complex. J. Plant Physiol. 2016, 194, 54-60. [CrossRef]

30. Janská, A.; Maršík, P.; Zelenková, S.; Ovesná, J. Cold stress and acclimation-what is important for metabolic adjustment? Plant Biol. 2010, 12, 395-405. [CrossRef]

31. Palma, F.; López-Gómez, M.; Tejera, N.A.; Lluch, C. Salicylic acid improves the salinity tolerance of Medicago sativa in symbiosis with Sinorhizobium meliloti by preventing nitrogen fixation inhibition. Plant Sci. 2013, 208, 75-82. [CrossRef]

32. Couée, I.; Sulmon, C.; Gouesbet, G.; El Amrani, A. Involvement of soluble sugars in reactive oxygen species balance and responses to oxidative stress in plants. J. Exp. Bot. 2006, 57, 449-459. [CrossRef]

33. Signorelli, S.; Coitiño, E.L.; Borsani, O.; Monza, J. Molecular mechanisms for the reaction between $\bullet \mathrm{OH}^{\mathrm{radicals}}$ and proline: Insights on the role as reactive oxygen species scavenger in plant stress. J. Phys. Chem. 2013, 118, 37-47. [CrossRef]

34. Curtis, T.; Halford, N.G. Food security: The challenge of increasing wheat yield and the importance of not compromising food safety. Ann. Appl. Biol. 2014, 164, 354-372. [CrossRef]

35. Chakrabarti, B.; Singh, S.D.; Kumar, V.; Harit, R.C.; Misra, S. Growth and yield response of wheat and chickpea crops under high temperature. Indian J. Plant Physiol. 2013, 18, 7-14. [CrossRef]

36. Cossani, C.M.; Reynolds, M.P. Physiological traits for improving heat tolerance in wheat. Plant Physiol. 2012, 160, 1710-1718. [CrossRef]

37. Narayanan, S. Effects of high temperature stress and traits associated with tolerance in wheat. Open Access. J. Sci. 2018, 2, 177-186.

38. Agarie, S.; Hanaoka, N.; Ueno, O.; Miyazaki, A.; Kubota, F.; Agata, W.; Kaufman, P.B. Effects of silicon on tolerance to water deficit and heat stress in rice plants (Oryza sativa L.), monitored by electrolyte leakage. Plant Prod. Sci. 1998, 1, 96-103. [CrossRef]

39. Sivanesan, I.; Son, M.; Soundararajan, P.; Jeong, B. Effect of silicon on growth and temperature stress tolerance of Nephrolepis exaltata "Corditas". Korean J. Horticult. Sci. Technol. 2014, 32, 142-148. [CrossRef]

40. Rios, J.J.; Martínez-Ballesta, M.C.; Ruiz, J.M.; Blasco, B.; Carvajal, M. Silicon-Mediated improvement in plant salinity tolerance: The role of aquaporins. Front. Plant Sci. 2017, 8, 948. [CrossRef]

41. Younis, A.A.; Khattab, H.; Emam, M.M. Impacts of silicon and silicon nanoparticles on leaf ultrastructure and TaPIP1 and TaNIP2 gene expressions in heat stressed wheat seedlings. Biol. Plant. 2020, 64, 343-352. [CrossRef]

42. Ma, D.; Sun, D.; Wang, C.; Qin, H.; Ding, H.; Li, Y.; Guo, T. Silicon application alleviates drought stress in wheat through transcriptional regulation of multiple antioxidant defense pathways. J. Plant Growth Regul. 2016, 35, 1-10. [CrossRef]

43. Wang, X.; Gao, F.; Bing, J.; Sun, W.; Feng, X.; Ma, X.; Zhou, Y.; Zhang, G. Overexpression of the jojoba aquaporin gene, scpip1, enhances drought and salt tolerance in transgenic Arabidopsis. Int. J. Mol. Sci. 2019, 20, 153. [CrossRef]

44. Abdel Latef, A.A.; Tran, L.S.P. Impacts of priming with silicon on the growth and tolerance of maize plants to alkaline stress. Front. Plant Sci. 2016, 7, 243. [CrossRef]

45. Alsaeedia, A.; El-Ramadyb, H.; Alshaa, T.; El-Garawanic, M.; Elhawat, N.; Al-Otaibi, A. Exogenous nanosilica improves germination and growth of cucumber by maintaining $\mathrm{K}^{+} / \mathrm{Na}^{+}$ratio under elevated $\mathrm{Na}^{+}$stress. Plant Physiol. Biochem. 2018, 125, 164-171. [CrossRef] [PubMed]

46. Hussain, A.; Rizwan, M.; Ali, Q.; Ali, S. Seed priming with silicon nanoparticles improved the biomass and yield while reduced the oxidative stress and cadmium concentration in wheat grains. Environ. Sci. Pollut. Res. 2019, 26, 7579-7588. [CrossRef] [PubMed]

47. Bajwa, A.A.; Chauhan, B.S.; Adkins, S. Morphological, physiological and biochemical responses of two Australian biotypes of Parthenium hysterophorus to different soil moisture regimes. Environ. Sci. Pollut. Res. 2017, 24, 16186-16194. [CrossRef] [PubMed]

48. O'Toole, J.C.; Moya, T.B. Genotypic variation in maintenance of leaf water potential in rice. Crop Sci. 1978, 18, 873-876. [CrossRef] 
49. Stirbet, A.; Govindjee, G. On the relation between the Kautsky effect (chlorophyll a fluorescence induction) and photosystem II: Basics and applications of the OJIP fluorescence transient. J. Photochem. Photobiol. B Biol. 2011, 104, 236-257. [CrossRef]

50. Metzner, H.; Rau, H.; Senger, H. Untersuchungen zur synchronisierbarkeit einzelner pigmentmangel-mutanten von Chlorella. Planta 1965, 65, 186-194. [CrossRef]

51. Fairbairn, N.J. A modified anthrone reagent. Chem. Ind. 1953, 4, 285-313.

52. Hubbard, N.L.; Pharr, D.M.; Huber, S.C. Role of sucrose phosphate synthase in sucrose biosynthesis in ripening bananas and its relationship to the respiratory climacteric. Plant Physiol. 1990, 94, 201-208. [CrossRef]

53. Bates, L.S.; Waldren, R.P.; Teare, I.D. Rapid determination of free prolin for water-stress studies. Plant Soil 1973, 39, $205-207$. [CrossRef]

54. Valentovič, P.; Luxová, M.; Kolarovič, L.; Gašparíková, O. Effect of osmotic stress on compatible solutes content, membrane stability and water relations in maize cultivars. Plant Soil Environ. 2006, 52, 186-191. [CrossRef]

55. Angelo, A.J.S.; Ory, R.L.; Brown, L.E. Comparison of methods for determining peroxidation in processed whole peanut products. J. Am. Oil Chem. Soc. 1975, 52, 34-35. [CrossRef]

56. Fishwick, M.J.; Swoboda, P.A. Measurement of oxidation of polyunsaturated fatty acids by spectrophotometric assay of conjugated derivatives. J. Sci. Food Agric. 1977, 28, 387-393. [CrossRef]

57. Tenea, G.N.; Bota, A.P.; Raposo, F.C.; Maquet, A. Reference genes for gene expression studies in wheat flag leaves grown under different farming conditions. BMC Res. Notes 2011, 4, 373. [CrossRef] [PubMed]

58. Livak, K.J.; Schmittgen, T.D. Analysis of relative gene expression data using real-time quantitative PCR and the $2^{-\Delta \Delta C T}$ method. Methods 2001, 25, 402-408. [CrossRef]

59. Chaves, M.M.; Flexas, J.; Pinheiro, C. Photosynthesis under drought and salt stress: Regulation mechanisms from whole plant to cell. Ann. Bot. 2009, 103, 551-560. [CrossRef]

60. Nolla, A.; de Faria, R.J.; Korndörfer, G.H.; da Silva, T.R.B. Effect of silicon on drought tolerance of upland rice. J. Food Agric. Environ. 2012, 10, 269-272.

61. Ashkavand, P.; Tabari, M.; Zarafshar, M.; Tomášková, I.; Struve, D. Effect of $\mathrm{SiO}_{2}$ nanoparticles on drought resistance in hawthorn seedlings. For. Res. Pap. 2015, 76, 350-359. [CrossRef]

62. Emam, M.M.; Khattab, H.I.; Helal, N.M. Effects of silicon or selenium on photosynthetic apparatus and antioxidant capacity of rice grown under drought condition. Egypt. J. Exp. Biol. 2012, 8, 271-283.

63. Saud, S.; Li, X.; Chen, Y.; Zhang, L.; Fahad, S.; Hussain, S.; Sadiq, A.; Chen, Y. Silicon application increases drought tolerance of Kentucky blue grass by improving plant water relations and morphophysiological functions. Sci. World J. 2014, 2014. [CrossRef]

64. Avestan, S.; Ghasemnezhad, M.; Esfahani, M.; Byrt, C.S. Application of Nano-Silicon Dioxide Improves Salt Stress Tolerance in Strawberry. Plant Agron. 2019, 9, 246. [CrossRef]

65. Sun, D.; Hussain, H.I.; Yi, Z.; Siegele, R.; Cresswell, T.; Kong, L.; Cahill, D.M. Uptake and cellular distribution, in four plant species of fluorescently labeled mesoporous silica nanoparticles. Plant Cell Rep. 2014, 33, 1389-1402. [CrossRef]

66. El Basyoni, I.; Saadalla, M.; Baenziger, S.; Bockelman, H.; Morsy, S. Cellmembrane stability and association mapping for drought and heat tolerance in a worldwide wheat collection. Sustainability 2017, 9, 1606. [CrossRef]

67. Rizwan, M.; Ali, S.; Rehman, M.Z.; Malik, S.; Adrees, M.; Qayyum, M.F.; Alamri, S.A.; Alyemeni, M.N.; Ahmad, P. Effect of foliar applications of silicon and titanium dioxide nanoparticles on growth, oxidative stress, and cadmium accumulation by rice (Oryza sativa). Acta Physiol. Plant. 2019, 41, 35. [CrossRef]

68. Nazaralian, S.; Majd, A.; Irian, S.; Najafi, F.; Ghahremaninejad, F.; Landberg, T.; Greger, M. Comparison of silicon nanoparticles and silicate treatments in fenugreek. Plant Physiol. Biochem. 2017, 115, 25-33. [CrossRef] [PubMed]

69. Merwad, A.R.M.; Desoky, E.S.M.; Rady, M.M. Response of water deficit-stressed Vigna unguiculata performances to silicon, proline or methionine foliar application. Sci. Hortic. 2018, 228, 132-144. [CrossRef]

70. Li-Feng, W.; Hao, F.; Yun-He, J. Photosynthetic characterization of a rolled leaf mutant of rice (Oryza sativa L.). Afr. J. Biotechnol. 2012, 11, 6839-6846. [CrossRef]

71. Chen, Q.; Zhao, X.; Lei, D.; Hu, S.; Shen, Z.; Shen, W.; Xu, X. Hydrogen-Rich water pretreatment alters photosynthetic gas exchange, chlorophyll fluorescence, and antioxidant activities in heat-stressed cucumber leaves. Plant Growth Regul. 2017, 83, 69-82. [CrossRef]

72. Jumrani, K.; Bhatia, V.S.; Pandey, G.P. Impact of elevated temperatures on specific leaf weight, stomatal density, photosynthesis and chlorophyll fluorescence in soybean. Photosynth. Res. 2017, 131, 333-350. [CrossRef]

73. Gosavi, G.U.; Jadhav, A.S.; Kale, A.A.; Gadakh, S.R.; Pawar, B.D.; Chimote, V.P. Effect of heat stress on proline, chlorophyll content, heat shock proteins and antioxidant enzyme activity in sorghum (Sorghum bicolor) at seedlings stage. Indian J. Biotechnol. 2014, 13, 356-363.

74. Yüzbaşığlu, E.; Dalyan, E.; Akpınar, I. Changes in photosynthetic pigments, anthocyanin content and antioxidant enzyme activities of maize (Zea mays L.) seedlings under high temperature stress conditions. Trakya Univ. J. Nat. Sci. 2017, 18, 97-104.

75. Djanaguiraman, M.; Boyle, D.L.; Welti, R.; Jagadish, S.V.K.; Prasad, P.V.V. Decreased photosynthetic rate under high temperature in wheat is due to lipid desaturation, oxidation, acylation, and damage of organelles. BMC Plant Biol. 2018, 18, 55. [CrossRef] [PubMed]

76. Teramura, A.H.; Sullivan, J.H. Effects of UV-B radiation on photosynthesis and growth of terrestrial plants. Photosynth. Res. 1994, 39, 463-473. [CrossRef] [PubMed] 
77. Cicek, N.; Fedina, I.; Çakirlar, H.; Velitchkova, M.; Georgieva, K. The role of short-term high temperature pretreatment on the UV-B tolerance of barley cultivars. Turk. J. Agric. For. 2012, 36, 153-165.

78. Tyutereva, E.V.; Evkaikina, A.I.; Ivanova, A.N.; Voitsekhovskaja, O.V. The absence of chlorophyll b affects lateral mobility of photosynthetic complexes and lipids in grana membranes of Arabidopsis and barley chlorina mutants. Photosynth. Res. 2017, 133, 357-370. [CrossRef]

79. Donegá, M.A. Ratio K: Ca and Application of Silicon in the Nutrient Solution for the Hydroponic Cultivation of Coriander. Master's Thesis, ESALQ, Piracicaba, Brazil, 2009; pp. 1-62.

80. Silva, E.N.; Vieira, S.A.; Ribeiro, R.V.; Ponte, L.F.; Ferreira-Silva, S.L.; Silveira, J.A. Contrasting physiological responses of Jatropha curcas plants to single and combined stresses of salinity and heat. J. Plant Growth Regul. 2013, 32, 159-169. [CrossRef]

81. Cao, B.L.; Ma, Q.; Zhao, Q.; Wang, L.; Xu, K. Effects of silicon on absorbed light allocation, antioxidant enzymes and ultrastructure of chloroplasts in tomato leaves under simulated drought stress. Sci. Hortic. 2015, 194, 53-62. [CrossRef]

82. Ju, S.M.; Wang, L.P.; Chen, J.Y. Effects of silicon on the growth, photosynthesis and chloroplast ultrastructure of Oryza sativa L. seedlings under acid rain stress. Silicon 2020, 12, 655-664. [CrossRef]

83. Haghighi, M.; Pessarakli, M. Influence of silicon and nano-silicon on salinity tolerance of cherry tomatoes (Solanum lycopersicum L.) at early growth stage. Sci. Hortic. 2013, 61, 111-117. [CrossRef]

84. Noji, T.; Kamidaki, C.; Kawakami, K.; Shen, J.R.; Kajino, T.; Fukushima, Y.; Sekitoh, T.; Itoh, S. Photosynthetic oxygen evolution in mesoporous silica material: Adsorption of photosystem II reaction center complex into $23 \mathrm{~nm}$ nanopores in SBA. Langmuir 2010, 27, 705-713. [CrossRef]

85. Colom, M.R.; Vazzana, C. Photosynthesis and PSII functionality of drought-resistant and drought-sensitive weeping love grass plants. Environ. Exp. Bot. 2003, 49, 135-144. [CrossRef]

86. Yoshioka, M.; Uchida, S.; Mori, H.; Komayama, K.; Ohira, S.; Morita, N.; Nakanishi, T.; Yamamoto, Y. Quality control of photosystem II cleavage of reaction center D1 protein in spinach thylakoids by FtsH protease under moderate heat stress. J. Biol. Chem. 2006, 281, 21660-21669. [CrossRef] [PubMed]

87. Komayama, K.; Khatoon, M.; Takenaka, D.; Horie, J.; Yamashita, A.; Yoshioka, M.; Nakayama, Y.; Yoshida, M.; Ohira, S.; Morita, N.; et al. Quality control of photosystem II: Cleavage and aggregation of heat-damaged D1 protein in spinach thylakoids. Biochim. Biophys. Acta Bioenerg. 2007, 1767, 838-846. [CrossRef] [PubMed]

88. Fan, J.; Hu, Z.; Xie, Y.; Chan, Z.; Chen, K.; Amombo, E.; Chen, L.; Fu, J. Alleviation of cold damage to photosystem II and metabolisms by melatonin in Bermuda grass. Front. Plant Sci. 2015, 6, 925. [CrossRef] [PubMed]

89. Ghassemi-Golezani, K.; Lotfi, R. The impact of salicylic acid and silicon on chlorophyll a fluorescence in mung bean under salt stress. Russ. J. Plant Physiol. 2015, 62, 611-616. [CrossRef]

90. Maghsoudi, K.; Emam, Y.; Ashraf, M. Influence of foliar application of silicon on chlorophyll fluorescence, photosynthetic pigments, and growth in water-stressed wheat cultivars differing in drought tolerance. Turk. J. Bot. 2015, 39, 625-634. [CrossRef]

91. Hussain, M.; Khan, T.A.; Yusuf, M.; Fariduddin, Q. Silicon-Mediated role of 24-epibrassinolide in wheat under high-temperature stress. Environ. Sci. Pollut. Res. 2019, 26, 17163-17172. [CrossRef]

92. Han, Y.; Fan, S.; Zhang, Q.; Wang, Y. Effect of heat stress on the MDA, proline and soluble sugar content in leaf lettuce seedlings. Agric. Sci. 2013, 4, 112. [CrossRef]

93. Mohamed, H.I.; Abdel-Hamid, A.M.E. Molecular and biochemical studies for heat tolerance on four cotton genotypes. Rom. Biotechnol. Lett. 2013, 18, 8823-8831.

94. Hasegawa, P.M.; Bressan, R.A.; Zhu, J.K.; Bohnert, H.J. Plant cellular and molecular responses to high salinity. Annu. Rev. Plant Biol. 2000, 51, 463-499. [CrossRef]

95. Kumar, S.; Gupta, D.; Nayyar, H. Comparative response of maize and rice genotypes to heat stress: Status of oxidative stress and antioxidants. Acta Physiol. Plant. 2012, 34, 75-86. [CrossRef]

96. Kohila, S.; Gomathi, R. Adaptive physiological and biochemical response of sugarcane genotypes to high-temperature stress. Indian J. Plant Physiol. 2018, 23, 245-260. [CrossRef] [PubMed]

97. Hameed, A.; Goher, M.; Iqbal, N. Heat stress-induced cell death, changes in antioxidants, lipid peroxidation, and protease activity in wheat leaves. J. Plant Growth Regul. 2012, 31, 283-291. [CrossRef]

98. Yin, L.; Wang, S.; Li, J.; Tanaka, K.; Oka, M. Application of silicon improves salt tolerance through ameliorating osmotic and ionic stresses in the seedling of Sorghum bicolor. Acta Physiol. Plant. 2013, 35, 3099-3107. [CrossRef]

99. Lana, R.M.Q.; Korndorfer, G.; Zanao-Junior, L.; Silva, A.; Lana, A.M.Q. Effect of calcium silicate on the productivity and silicon accumulation in the tomato plant. Biosci. J. 2003, 19, 15-20.

100. Meena, V.D.; Dotaniya, M.L.; Coumar, V.; Rajendiran, S.; Kundu, S.; Rao, A.S. A case for silicon fertilization to improve crop yields in tropical soils. Proc. Natl. Acad. Sci. India Sect. B J. Biol. Sci. 2014, 84, 505-518. [CrossRef]

101. Kalteh, M.; Alipour, Z.T.; Ashraf, S.; Aliabadi, M.M.; Nosratabadi, A.F. Effect of silica nanoparticles on Basil (Ocimum basilicum) under salinity stress. J. Chem. Health Saf. 2014, 4, 49-55.

102. Abdel-Haliem, M.E.F.; Hegazy, H.S.; Hassan, N.S.; Naguib, D.M. Effect of silica ions and nano silica on rice plants under salinity stress. Ecol. Eng. 2017, 99, 282-289. [CrossRef]

103. Lípová, L.; Krchňák, P.; Komenda, J.; Ilík, P. Heat-Induced disassembly and degradation of chlorophyll-containing protein complexes in vivo. Biochim. Biophys. Acta 2010, 1797, 63-70. [CrossRef] 
104. Ifuku, K.; Endo, T.; Shikanai, T.; Aro, E. Structure of the Chloroplast NADH Dehydrogenase-Like Complex: Nomenclature for Nuclear-Encoded Subunits. Plant Cell Physiol. 2011, 52, 1560-1568. [CrossRef]

105. Fristedt, R.; Willig, A.; Granath, P.; Crèvecoeur, M.; Rochaix, J.D.; Vener, A.V. Phosphorylation of photosystem II controls functional macroscopic folding of photosynthetic membranes in Arabidopsis. Plant Cell 2009, 21, 3950-3964. [CrossRef]

106. Vener, A.V.; Rokka, A.; Fulgosi, H.; Andersson, B.; Herrmann, R.G. A cyclophilin-regulated PP2A-like protein phosphatase in thylakoid membranes of plant chloroplasts. Biochemistry 1999, 38, 14955-14965. [CrossRef] [PubMed]

107. Liu, W.J.; Chen, Y.E.; Tian, W.J.; Du, J.B.; Zhang, Z.W.; Xu, F.; Zhang, F.; Yuan, S.; Lin, H.H. Dephosphorylation of photosystem II proteins and phosphorylation of CP29 in barley photosynthetic membranes as a response to water stress. Biochim. Biophys. Acta Bioenerg. 2009, 1787, 1238-1245. [CrossRef] [PubMed]

108. Varghese, N.; Alyammahi, O.; Nasreddine, S.; Alhassani, A.; Gururani, M.A. Melatonin positively influences the photosynthetic machinery and antioxidant system of Avena sativa during salinity stress. Plants 2019, 8, 610. [CrossRef] [PubMed]

109. Rantala, M.; Rantala, S.; Aro, E.M. Composition, phosphorylation and dynamic organization of photosynthetic protein complexes in plant thylakoid membrane. Photochem. Photobiol. Sci. 2020, 19, 604-619. [CrossRef]

110. Gururani, M.A.; Venkatesh, J.; Tran, L.S.P. Regulation of photosynthesis during abiotic stress-induced photoinhibition. Mol. Plant 2015, 8, 1304-1320. [CrossRef]

111. Sasi, S.; Venkatesh, J.; Daneshi, R.F.; Gururani, M.A. Photosystem II extrinsic proteins and their putative role in abiotic stress tolerance in higher plants. Plants 2018, 7, 100. [CrossRef]

112. Wei, X.; Su, X.; Cao, P.; Liu, X.; Chang, W.; Li, M.; Zhang, X.; Liu, Z. Structure of spinach photosystem II-LHCII super complex at 3.2 Å resolution. Nature 2016, 534, 69. [CrossRef]

113. Takahashi, S.; Nakamura, T.; Sakamizu, M.; Woesik, R.V.; Yamasaki, H. Repair machinery of symbiotic photosynthesis as the primary target of heat stress for reef-building corals. Plant Cell Physiol. 2004, 45, 251-255. [CrossRef]

114. Kamiya, N.; Shen, J.R. Crystal structure of oxygen-evolving photosystem II from Thermosynechococcus vulcanus at 3.7-Å resolution. Proc. Natl. Acad. Sci. USA 2003, 100, 98-103. [CrossRef] 